\title{
Combined Thermal Insulating Module of Mounted Vented Facades
}

\author{
Svetlana Ryabukhina ${ }^{1, *}$, Tatjana Simankina ${ }^{1}$, Marina Koshkarova $^{2}$, Nikita Sokolovskii ${ }^{1}$ \\ and Oleg Ryzhkov ${ }^{3}$ \\ ${ }^{1}$ St.-Petersburg State Polytechnical University, 195251 Politechnicheskaya St. 29, St. Petersburg, \\ Russian Federation \\ ${ }^{2}$ Ltd «Teploizolyatsiya ograzhdayushchikh konstruktsiy», 197342 Torshkovskaja St. 1, St.Petersburg, \\ Russian Federation \\ ${ }^{3}$ Ltd «URSA EURASIA», 196191 Leninskij Ave., 168, St.Petersburg, Russian Federation
}

\begin{abstract}
In order to define an optimum type of mounted vented facades among the existing ones, comparative analysis of two façade modules has been conducted. The first module type is a widespread standard module of hinged vented facade and the second type is less applicable combined thermal insulating module. Those two technologies were compared thermal engineering and energy efficiency parameters. It was defined that the application of a thermal insulating module with combined insulation system improves thermal engineering parameters of the building as well as leads to a substantial savings. This article exposes innovative materials and structure of vented facades which can be applied in modern construction.
\end{abstract}

\section{Introduction}

System of mounted vented facades (MVF) have found it's wide application in the construction market [1], although, despite the wholesale application, there are some aspects which require modernization [2]. At the current developmental stage of construction the increasing of energy efficiency and energy saving indexes [3] of buildings and structures with different purposes remains the major challenge.

As discussed elsewhere $[4,5,6]$ it is possible to figure out the solution of those tasks only by the means of complex approach for the building construction itself, not by examining it's separated components. The other problem is defining the economic effectiveness. This task also demands for a complex approach, taking into account the whole cycle of construction and mounting works, and also the logistic costs, expenses for the storage and cargo works, not to take the distinct costs of construction materials for the unit of measure.

Authors Haase, Pukhkal, Penic [7, 8, 9] evaluates different design and configuration ventilated facade in respect to the amount of energy saved.

The optimal solution has to be found among the existing options of mounted ventilated facades (MVF), knowing the problems of a particular structure.

\footnotetext{
${ }^{*}$ Corresponding author: snowflake2203@yandex.ru
} 
Let us compare a wide-applicable constructional solution of a MVF - the standard module and a less common one, though selectively applicable combined thermal insulating module for the thermal engineering and economic efficiency parameters.

\section{Comparison of existing and optimize thermal insulation modules}

Today the popular solution of MVF is a double-layered heat-insulating module made of mineral wool plates obtained from basalt rocks, where both layers are mechanically fastened to base - the wall. The whole structure itself fastens to the suspension system made of corrosion-resistant galvanized steel with polymer coating. Facing is made of porcelain stoneware slabs $[10,11,12]$. Along with the obvious advantages, such as highclass fire safety construction design (R0), which is allowing you to apply this structure with no restrictions for the building height, there is also a number of indicators that needs to be refined.

One of the constructional optimization options can be the application of the combined heat- insulating module, for example, the MVF PARURS structure. The structure consists of thermal insulating module with internal layer made of fiberglass staple plates (with a proper thickness according to thermal engineering calculations for the application region), which are fixed on the cantilevers of mounted system without and additional bracing. It also consists of a blanket with a thickness of more than $30 \mathrm{~mm}$ made of mineral wool plates obtained from basalt rocks, which is fixed on cantilevers of the mounted system with an additional bracing. As a windproof layer the materials with a high-class fire safety construction design (R0) are used [13]. Otherwise the construction has the standard MVF construction system.

Benefits of that kind of structure are the following parameters: minimization of thermal bridges, the improvement of layer uniformity index, improved heat-resistance index, which leads to increased energy efficiency as well as economic benefits during construction and installation works, storage and logistics.

Let us compare those types of heat-insulating modules.

One of the demands during the mount of heat-insulating plates in two layers is a fixing the first layer plates with a poppet head dowels with $110 \mathrm{~mm}$ head diameter or with poppet head dowels with additional $140 \mathrm{~mm}$ shims irrespectively to the attachment of the second layer [14]. On the basis of the technical solutions album ATS-01-2014, inner insulating layer of the PARURS structure is hung directly on brackets of the suspension system without additional mechanical fixing, which clearly reduces the amount of thermal bridges in the heat-insulating unit [15].

It should be noted that the outer walls of the constructions, unfortunately, don't always have a flat, smooth structure (Figure 1). 


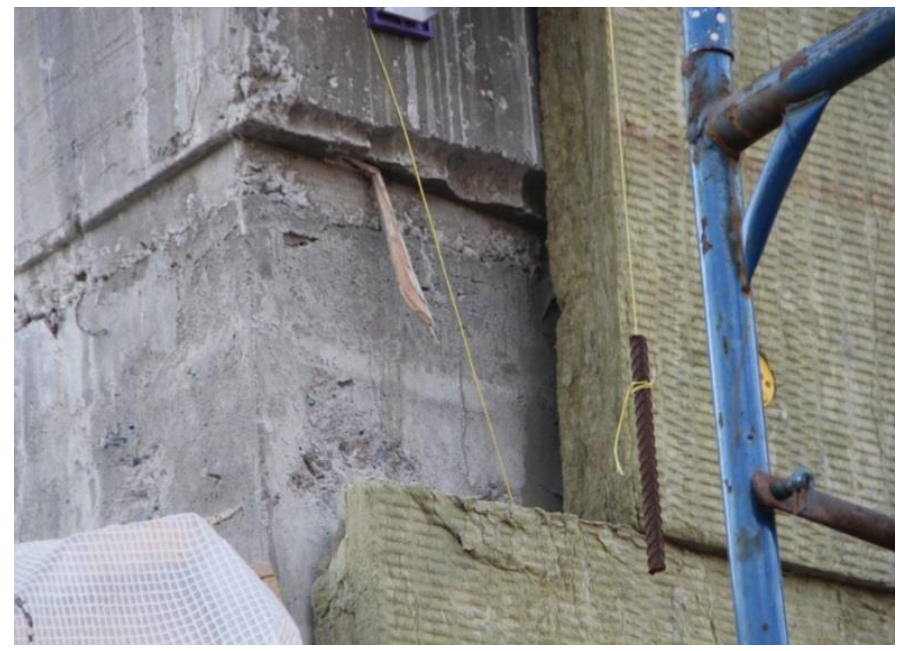

Fig. 1. The roughness on the outer wall construction

Comparing modules for the fit force of the inner heat insulating layer in enclosing structure revealed that mineral wool plates obtained from basalt rocks cannot always provide the required density and elasticity of the fit [16], while the use of a combined heatinsulating module shows a snug fit of insulation to the wall with a roughness and fills the irregularities of the boundary wall (Figure 2).

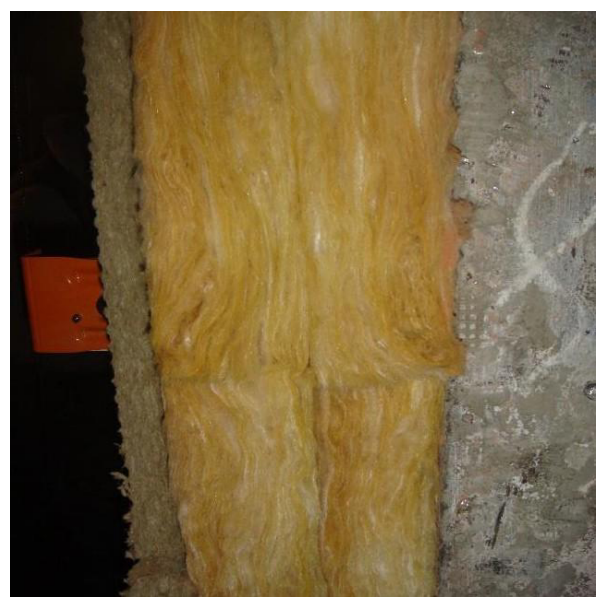

Fig. 2. The fit of a combined heat-insulating module to the wall with roughness

Heat transfer resistance of the outer walls in accordance with the thermal calculations, particularly for Saint-Petersburg, is $3.83\left(\mathrm{~m}^{2} \cdot{ }^{\circ} \mathrm{C} / \mathrm{W}\right)$. Heat-insulating module made of two layers of mineral wool plates obtained from basalt rocks equals this parameter with the use of $150 \mathrm{~mm}$ heat-insulating layer. Combined heat-insulating module with the same thickness of the heat- insulating layer shows a $4.03\left(\mathrm{~m}^{2} \cdot{ }^{\circ} \mathrm{C} / \mathrm{W}\right)$ index, which indicates more efficient heat-insulation in the structure [17].

In order to compare economic efficiency estimates were made for each type of construction with equal areas of the facade (Table 1, Table 2). Calculations during the mount of $1000 \mathrm{~m}^{2}$ of the facade showed that combined system of insulation is 4400 euros cheaper than the standard one. 
Table 1. Cost estimates of mounting $1000 \mathrm{~m}^{2}$ of a combined module structure

\begin{tabular}{|c|c|c|c|c|c|c|}
\hline № & Name & $\begin{array}{l}\text { Measure } \\
\text { units }\end{array}$ & $\begin{array}{c}\text { Laboriousnes } \\
\mathrm{s}, \text { man-hour/ } \\
\text { machine } \\
\text { hour }\end{array}$ & Amount & $\begin{array}{c}\text { Unit value, } \\
\text { rub. }\end{array}$ & $\begin{array}{l}\text { Total cons, } \\
\text { rub. }\end{array}$ \\
\hline & $\begin{array}{l}\text { Mounting of vented facades with } \\
\text { a porcelain facing and thermal } \\
\text { insulation layer } \\
\text { Overhead cost: } 105 \% \text { of Wages } \\
\text { fund } \\
\text { Estimated profit: } 55 \% \text { Wages } \\
\text { fund }\end{array}$ & $\begin{array}{c}\mathrm{m}^{2} \\
\text { of facing }\end{array}$ & & 1000 & 263.29 & 263288.12 \\
\hline 1 & Manning of workers & man- hour & 2.400 & 2399.865 & 60.13 & 144291.88 \\
\hline 2 & Manning of machinists & man- hour & 0.258 & 258.16 & 72.50 & 18716.60 \\
\hline \multicolumn{7}{|c|}{ Machinery } \\
\hline 3 & $\begin{array}{c}\text { Lifts with a capacity up to } 500 \\
\mathrm{~kg} \text {, single-masted, elevating } \\
\text { height } 35 \mathrm{~m}\end{array}$ & $\begin{array}{l}\text { machine } \\
\text { hour }\end{array}$ & 0.258 & 258.16 & 111.63 & 28817.11 \\
\hline 4 & Screwdriver & $\begin{array}{l}\text { machine } \\
\text { hour }\end{array}$ & 0.131 & 130.575 & 18.75 & 2448.28 \\
\hline 5 & Drills: electric & $\begin{array}{l}\text { machine } \\
\text { hour }\end{array}$ & 0.384 & 383.55 & 12.19 & 4674.52 \\
\hline 6 & Electric grinding machines & $\begin{array}{l}\text { machine } \\
\text { hour }\end{array}$ & 0.070 & 69.6 & 32.06 & 2231.55 \\
\hline \multirow[t]{6}{*}{7} & $\begin{array}{l}\text { Electric } 1.5 \mathrm{~kW} \text { hammer with } \\
\text { impact energy up to } 18 \mathrm{~J}\end{array}$ & $\begin{array}{l}\text { machine } \\
\text { hour }\end{array}$ & 0.378 & 378.42 & 164.13 & 62108.18 \\
\hline & & & & & Total: & 263288.12 \\
\hline & Overhead cost & $105 \%$ & & & & 171158.91 \\
\hline & Estimated profit & $55 \%$ & & & & 89654.67 \\
\hline & & & & & Total: & 524101.70 \\
\hline & & & & & VAT $18 \%$ : & 94338.31 \\
\hline 4 & Screwdriver & $\begin{array}{l}\text { machine } \\
\text { hour }\end{array}$ & 0.131 & 130.575 & 18.75 & 2448.28 \\
\hline \multirow[t]{2}{*}{5} & Drills: electric & $\begin{array}{l}\text { machine } \\
\text { hour }\end{array}$ & 0.384 & 383.55 & 12.19 & 4674.52 \\
\hline & & & & \multicolumn{2}{|c|}{$\begin{array}{c}\text { Overall with VAT } \\
18 \%:\end{array}$} & 618440.00 \\
\hline
\end{tabular}


Table 2. Cost estimates of mounting $1000 \mathrm{~m}^{2}$ of a standard module structure

\begin{tabular}{|c|c|c|c|c|c|c|}
\hline № & Name & $\begin{array}{l}\text { Measure } \\
\text { units }\end{array}$ & $\begin{array}{c}\text { Laboriousnes } \\
\text { s, man-hour/ } \\
\text { machine } \\
\text { hour }\end{array}$ & Amount & $\begin{array}{l}\text { Unit } \\
\text { value, } \\
\text { rub. }\end{array}$ & $\begin{array}{l}\text { Total cons, } \\
\text { rub. }\end{array}$ \\
\hline & $\begin{array}{c}\text { Mounting of vented facades with } \\
\text { a porcelain facing and thermal } \\
\text { insulation layer Overhead cost: } \\
105 \% \text { of Wages fund } \\
\text { Estimated profit: } 55 \% \text { Wages } \\
\text { fund }\end{array}$ & $\begin{array}{l}\mathrm{m}^{2} \text { of } \\
\text { facing }\end{array}$ & & 1000 & 390.35 & 390347.40 \\
\hline 1 & Manning of workers & man-hour & 3.6921 & 3692.1 & 60.13 & 221987.51 \\
\hline 2 & Manning of machinists & man-hour & 0.3688 & 368.8 & 72.50 & 26738.00 \\
\hline \multicolumn{7}{|c|}{ Machinery } \\
\hline 3 & $\begin{array}{c}\text { Lifts with a capacity up to } 500 \mathrm{~kg}, \\
\text { single-masted, elevating height } 35 \\
\mathrm{~m}\end{array}$ & $\begin{array}{l}\text { machine } \\
\text { hour }\end{array}$ & 0.3688 & 368.8 & 111.63 & 41167.30 \\
\hline 4 & Screwdriver & $\begin{array}{c}\text { machine } \\
\text { hour }\end{array}$ & 0.1741 & 174.1 & 18.75 & 3264.38 \\
\hline 5 & Drills: electric & $\begin{array}{c}\begin{array}{c}\text { machine } \\
\text { hour }\end{array} \\
\end{array}$ & 0.5114 & 511.4 & 12.19 & 6232.69 \\
\hline 6 & Electric grinding machines & $\begin{array}{l}\text { machine } \\
\text { hour }\end{array}$ & 0.0696 & 69.6 & 32.06 & 2231.55 \\
\hline \multirow[t]{7}{*}{7} & $\begin{array}{l}\text { Electric } 1.5 \mathrm{~kW} \text { hammer with } \\
\text { impact energy up to } 18 \mathrm{~J}\end{array}$ & $\begin{array}{c}\text { machine } \\
\text { hour }\end{array}$ & 0.5406 & 540.6 & 164.13 & 88725.98 \\
\hline & & & & & Total: & 390347.40 \\
\hline & Overhead cost & $105 \%$ & & & & 261161.79 \\
\hline & Estimated profit & $55 \%$ & & & & 136799.03 \\
\hline & & & & & Total: & 788308.22 \\
\hline & & & & & $\begin{array}{l}\text { VAT } \\
18 \% \text { : }\end{array}$ & 141895.48 \\
\hline & & & & \multicolumn{2}{|c|}{$\begin{array}{c}\text { Overall with VAT } \\
18 \% \text { : }\end{array}$} & 930203.70 \\
\hline
\end{tabular}

\section{Results and Discussion}

The comparison of a widely applicable standard module of MVF to the optimized less applicable combined heat-insulating module structure solution based on the standard structure on the basis of thermal engineering and economic efficiency parameters, as well as sound absorbing characteristics of the heat-insulating layer, it was concluded that the application of the heat- insulating unit with combined insulation system not only improves the thermal performance of buildings, but also leads to a significant economic effect. The future is about neoteric technologies. Even if it seems utmost was invented earlier, we 
possess a wide range of activity lines for implementation of something new, original and more effective. For today combined module PAPURS is only coming to market and hasn't been tried on practice yet. This construction was patented in Russia this year. Although, many specialists have already estimated it's properties and are ready to implement it.

\section{Conclusion}

Based on the conducted comparison methodology authors obtained following data:

- heat-insulating module of a combined type is $4.03\left(\mathrm{~m}^{2} \cdot{ }^{\circ} \mathrm{C} / \mathrm{W}\right)$ combined to $3.83\left(\mathrm{~m}^{2} \cdot{ }^{\circ} \mathrm{C} / \mathrm{W}\right)$ of a standard system [17];

- from the point of economical effectiveness the usage of combined module leads to the significant economic effect (mounting $1000 \mathrm{~m}^{2}$ of combined module is 4400 euros cheaper comparing to standard type).

\section{References}

1. Rynok ventiliruemyh fasadov, Ventiliruemye fasady «SK Divart» - Jelektronnyj resurs: http://sk-divart.ru/rynok- ventiliruemyh-fasadov

2. A.S. Gorshkov, D.V. Nemova, N.I. Vatin, Stroitel'stvo unikal'nyh zdanij i sooruzhenij, 7, 49-63 (2013)

3. D.V. Nemova, Jenergojeffektivnye tehnologii $\mathrm{v}$ ograzhdajushhih konstrukcijah, Stroitel'stvo unikal'nyh zdanij i sooruzhenij, 3, 78-82 (2012)

4. A. Milajić, D. Beljaković, N. Davidović, N.I. Vatin, V. Murgul, Procedia Engineering, 117, 916-923 (2015).

5. N. Harmati, Ž Jakšić, N.I. Vatin, Procedia Engineering, 117, 791-799 (2015)

6. M. Tanic, D. Stankovic, V. Nikolic, M. Nikolic, D. Kostic, A. Milojkovic, S. Spasic, N.I. Vatin, Procedia Engineering, 117, 924-937 (2015)

7. M. Haase, F. Marques da Silva, A. Amato, Energy and Buildings, 41, 361-373 (2009)

8. V. Pukhkal, M. Tanić, N.I Vatin, V. Murgul, Procedia Engineering, 117, 864-869 (2015)

9. M. Penić, N.I. Vatin, V. Murgul, Applied Mechanics and Materials, 680, 534-538 (2014).

10. L. Svatovskaya, A. Sychova, M. Sychov, V. Okrepilov, MATEC Web of Conferences, 53, Article Number 01023 (2016)

11. D. Terentyev et al, Fasadnye teploizoljacionnye sistemy s vozdushnym zazorom. Rekomendacii po sostavu i soderzhaniju dokumentov i materialov, predstavljaemyh dlja tehnicheskoj ocenki prigodnosti produkcii (first ed., Gosstroj Rossii, Moscow, 2004)

12. Information on - URL: http://www.minplita.biz/solutions/50/.

13. № 123-FL (Federal Law) «Tehnicheskij reglament o trebovanijah pozharnoj bezopasnosti»

14. Information on http://www.minplita.biz/solutions/50/

15. Al'bom tehnicheskih reshenij ATR - 01 - 2014 «Sistema ventiliruemyh fasadov PARURS» (2014)

16. Information on : http://stoydiz.ru/pokraska-i-otdelka/montazh-ventiliruemyhfasadov.html.

17. CP (Code of Practice) 50.13330.2012 «Teplovaja zashhita zadnij» 